\title{
Yazılı ve İkonografik Kaynaklara Göre Antik İran'da (Persler, Parthlar, Sâsânîler) Hâkimiyet Anlayışı: Tanrısal Seçim
}

\author{
Muzaffer Duran*
}

$\ddot{O} z$

İktidarın kaynağına dair ideolojiler devletlerin meşruiyetinin dayandığı temel unsurlardan biridir. Devletlerin hâkimiyet anlayışını yansıtan bu ideolojilerden biri hükümdarın ve onun üyesi olduğu hanedanlığın kutsiyeti düşüncesine dayanan ilahi destektir. Eski İran tarihinde egemenliğin ve iktidarın kaynağı dini temeller çerçevesinde gelişen bir yapı arz etmektedir. Bunun esasını hükümdarın tanrı ile olan iyi (doğruluk, adalet, düzen) veya kötü (yalan, kargaşa) münasebeti oluşturmaktadır. Bu iliş̧i çerçevesinde hükümdarın tanrı ile ilişkisi "iyi”" üzerineyse tanrının ona hükümdarlık yetkisi bağışladığına inanılırdı. Ancak hükümdar kötü bir yönetim sergilerse yönetme erki yine tanrı tarafından geri alınırdı. Tanrı ve hükümdar arasındaki bu ilişki Eski İran'ın yazılı ve arkeolojik kaynaklarında ifade edilmiştir. Bu hususta Avesta metinlerinden Yasna ve Yaşt bölümleri ile Pers ve Sâsânî dönemi yazıtları hükümdarlık geleneği çerçevesinde tanrısal seçim/ yetki anlayışını yansıtmaktadır. İkonografik kaynaklarda da bu durum birtakım kutsal anlamlar yüklenen sembollerle ifade edilmiştir. Bu çalışmanın amacı da Eski İran'daki Pers, Parth, Sâsânî hanedanlıkları döneminde tanrısal seçim ideolojisinin yazılı ve ikonografik kaynaklardaki yansımalarını incelemek ve bu ideolojinin söz konusu hanedanlıklardaki tarihi seyrini takip etmektir. Bu hususta Eski İran'da söz konusu hanedanlıklar döneminde hükümdarın tanrı tarafından seçilmiş bir temsilci olduğu, buna rağmen iktidarı elde etmenin de bazı şartlarının bulunduğu anlaşılmaktadır. Bu şartın temeli ise tanrının lütfunu kazanmaktır. Bu amaç için dindar bir kral imajı yaratılmıştır. Bunun yanında tanrısal seçim ideolojisinin bir sonucu olarak Pers ve Sâsânî dönemine ait kaynaklarda dünya hâkimiyeti fikri ortaya çıkmıştır. Bütün bu ideoloji yazılı ve görsel araçlarla bir mesaj olarak sunulmuş ve dolayısıyla meşruiyet propagandasının da bir aracı haline gelmiştir.

Anahtar Kelimeler: Eski İran, İktidar, Hâkimiyet, Hükümdarlık, Tanrısal Seçim.

Dr. Öğr. Üyesi, Süleyman Demirel Üniversitesi, Fen Edebiyat Fakültesi, Tarih Bölümü, Isparta, Türkiye, muzafferduran@sdu.edu.tr, ORCID: 0000-0001-8209-1759 


\title{
The Divine Choice: The Source of Power in Ancient Iran (Persians, Parthians, Sasanians) in the Light of Written and Iconographic Evidence
}

\author{
Muzaffer Duran*
}

\begin{abstract}
Ideologies with regard to the source of power are one of the basic elements that the legitimacy of states based on. One of these ideologies, which reflect the perception of sovereignty of states, is divine support based on the idea of the sanctity of the ruler and the dynasty of which the ruler is a member. The source of sovereignty and power in the history of Ancient Iran represents a structure that develops in the scope of religious principals. The main point of this is the good (truth, justice, order) or bad (lie, chaos) relationship of the ruler with god. According to this relationship, it was believed that if the ruler had a good relationship with the god, god bestow power (Glory) to the ruler. However, if the ruler showed misgovern on the country, the power was taken back by the god. This relationship between god and the ruler was expressed in written and archaeological sources in ancient Iran. In this regard, the Yasna and Yasht sections of the Avesta and the Persian and Sasanian inscriptions reflect the divine choice/authority. In iconographic sources, divine choice was illustrated by the symbols with some sacred meanings. The aim of this study is to examine the reflections of the divine choice ideology in written and iconographic sources during the Persian, Parthian and Sasanian period in ancient Iran and to trace the historical course of this ideology in the mentioned dynasties. In this regard, it is understood that the ruler in the mentioned dynasties period was a representative chosen by god, but there were some obligations that needs to be fulfilled by him in order to take the power. The basis of this is to gain the grace of god. For this purpose, the image of a pious king was created. As a result of the divine choice ideology, the idea of world domination emerged in the sources of the Persian and Sasanian periods. Divine choice ideology was presented as a message with the written and visual materials and therefore it became a symbol of the legitimacy propaganda.
\end{abstract}

Keywords: Ancient Iran, Power, Sovereignty, Rulership, Divine Choice.

Asst. Prof., Süleyman Demirel Univesity, Faculty of Science and Letters, Department of History, Isparta, Turkey, muzafferduran@sdu.edu.tr, ORCID: 0000-0001-82091759 


\section{Giriş}

Devletlerin hâkimiyet anlayışında iktidarın kaynağı hususundaki temel ideolojilerden biri karizmatik hâkimiyet düşüncesidir. Bu ideolojinin temelini hükümdar ve tanrı arasındaki ilişki oluşturmaktadır. Söz konusu münasebetin odak noktası ise tanrısal seçim/yetki anlayışıdır. Bu anlayışa göre hükümdar olacak kişiyi tanrı tayin eder, bu kişiye tanrı tarafından üstün yetenekler bahşedilir ve böylece seçilmiş kişi tanrı korumasına mazhar olur (Kafesoğlu, 2005, s. 248). Bu ideoloji Eski Çağdan itibaren birçok devletin hâkimiyet anlayışında yerini almıştır. Zira Eski Mezopotamya geleneğinde hükümdarlar, tanrısal irade ile yönetme gücünü elde ettiğini iddia etmekteydi. Bu konuda bir Sümer kral listesi, Tufandan önce yeryüzünü yönetme görevinin bir hanedanlığa verildiğinden bahseder. Tufandan sonra ise yönetimlerin el değiştirmesinin savaş yoluyla olduğu, bu savaşları kazanıp hâkimiyeti elde eden hükümdarın bu işleri "tanrının izni” ile başardığı anlatılmaktadır (Nadali, 2015, s. 309-310).

Eski İran tarihinde de iktidarın kaynağı hususunda tanrısal seçim düşüncesine dair kanıtlar mevcuttur. Eski İran'daki bu düşüncenin kökleri Avesta'da ve Zerdüşt inancın esaslarında yatmaktadır. Zerdüşt'ün yaşadığ dönem konusunda kesin bir bilgi olmasa da MÖ 6. yüzylldan itibaren Pers hükümdarlarının yazıtlarında Zerdüştî inanca ait olan Ahura Mazda (Kent, 1950, s. 119-134, 138, 147-150 (DB, DNa, XP, vd)), Anahita ve Mithra'ya (Kent, 1950, s. 154-156 (A ${ }^{2} \mathrm{Ha}$, b; $\left.\mathrm{A}^{2} \mathrm{Sa} ; \mathrm{A}^{3} \mathrm{~Pa}\right)$ ) dair atıflar bulmak mümkündür. Bu hususta M. B. Garrison (2011, s. 21) Perslerin veya en azından yönetici seçkinlerin Zerdüşt inancına sahip olduğunu düşünmektedir. ${ }^{1}$

Zerdüştlüğün evrensel bir kurtuluş dini olarak görülmesi, İran hükümdarlarının bu durumu ideolojik olarak kullanmasını sağlamıştır (Mann, 2012, s. 285). Bu ideoloji şemasının en tepesinde Ahura Mazda yer almaktadır. $\mathrm{Bu}$ isim, tanr/efendi anlamına gelen Ahura ve bilge anlamına gelen Maz$d a$ kelimelerinin birleşiminden oluşmuştur. Zerdüşst inanışta Ahura Mazda "iyi olan her şeyin yaratıcısı", diğer tüm kutsallar da dâhil olmak üzere sonsuza dek var olan yaratılmamış tanrıdır (Garrison, 2011, s. 21). Bu inanışa göre dünyayı düzene koymak için tanrı tarafından bir hükümdar yetkilendirilmiştir (Daryaee, 2009, s. 42). Eski İran'da hüküm sürmüş olan

Zerdüşt’ün yaşadığı dönem hakkındaki düşünceler için bknz. Eliade, 2017, s. 418-419; Henning, 1951, s. 3-17. 
Pers (Akhaimenid Hanendalığı), Parth (Arsak Hanedanlığı) ve Sâsânî devletlerinde de iktidarın kaynağı tanrısal seçime dayandırılmıştır. Bu çalışmada öncelikle tanrısal seçim ideolojisinin dini temelleri için başta Avesta metinlerinde geçen tanrı ve hükümdar münasebeti; ardından bu ilişkinin söz konusu hanedanlıklara ait yazıtlar, rölyefler, sikke ve mühürlerde ifade ediliş biçimleri ele alınmıştır. Bunun yanında bazı Eski Yunan ve Roma yazılı kaynakları da konu ve kapsam çerçevesinde çalışmaya dahil edilmiştir.

\section{Tanrısal Seçim Düşüncesinde Zerdüştî İnancın Rolü}

Hint Avrupa dil ailesinin Hint-İran sınıfının İran kolunda, Doğu İran lehçesi ile yazılmış olan Avesta, Zerdüşt öğretilerinin yazılı olduğu metinlerdir. Kaynaklarda Büyük İskender'den önce Avesta metinlerinin var olduğu, İstahr'da² saklandığı ancak Büyük İskender'in bu metinleri yaktığı yönünde bir anlayış bulunmaktadır (Malandra, 1983, s. 30). Söz konusu metinler Parth ve Sâsânî hükümdarlarının çabaları neticesinde tekrar bir araya getirilmiştir (Garrison, 2011, s. 22).

Avesta'nın Vendîdâd bölümünde maddi dünyayı, dünya üzerindeki diyarları ve ülkeleri yaratan Ahura Mazda olduğu ifade edilmektedir (Darmesteter, 1895, s. 2-49 (Vendîdâd, Fargard I-IV)). Avesta'ya göre Ahura Mazda evrendeki kaos ile savaşıp kainattaki düzeni sağlamıştır. Dünyadaki kaosu da (kötülüğ̈̈) düzene (iyiliğe) çevirmek için bir hükümdar görevlendirmiştir (Daryaee, 2009, s. 42). Avesta metinleri ayrıca seçilmiş olan hükümdarın evrensel olduğunu, yani tüm dünyayı idare etmek için yetkilendirildiğini belirtmektedir (Darmesteter, 1883, s. 79 (5. Âbân Yaşt (25); Mills, 1965, s. 283 (Yasna 35.5)).

Avesta'da tanrı tarafından kişiye verilen yönetme yetkisi $x^{v}$ arenō/khvareno (ferr, ferre, farr) kelimesi ile karşılanmaktadır (Hintze, 1994 (19. Zamyâd Yaşt)). Kelime Hotan dilinde farra, Soğdcada prn, Kuşhan-Baktria dilinde farro olarak ifade edilir (Malandra, 1983, s. 88). Kelime Yunan kaynaklarında genellikle Tykhe ve Daimon, Latin kaynaklarında ise Fortuna olarak geçmektedir (Shahbazi, 1980, s. 129). Ferr anlayışı İran'da ulusal bir

Persepolis'in 7 km. kuzeyinde, Haciâbâd köyü (Uslu, 2001, s. 202). İbnu'l-Belhî’nin Farsnâme adlı eserinde Zerdüşt kitabının İstahr yakınlarındaki Nefşet Dağı'nda bulunduğu ifade edilir (Bakır, 2008, s. 110). 
anlayış (Airyanam xvaranah=Ferr-i Îrânî) olarak görülmüştür (Yarshater, 2006b, s. 408). Görkem, ululuk, mutluluk, aydınlık, büyüklük, şan, layık olma, yaraşırlık anlamlarına gelen ferr, Avesta'nın Zamyâd Yaşt bölümünde tanrısal/ilahi 1şık olarak adlandırılmaktadır: "Bu ışığın aydınlığıyla kişi hükümdarlığa erişir, taht ve tacı ele geçirir. Sözcüğün insanlar için anlamı hayatı boyunca yaptığı iyiliklerdir." (Yıldırım, 2008, s. 316; Hintze, 1994 (19. Zamyâd Yaşt)). Avesta'da ve Pehlevi edebiyatında da "bereket, ikbal ve baht" (Yıldırım, 2008, s. 316; West, 1897, s. 9 (Dîn. VII. 22-25); Peterson, 2002, s. 161 (Bundehişn XXXIII.6-8); Hintze, 1994, s. 20-22 (19. Zamyâd Yaşt (31-38)) kavramları ile ilişkilendirilmektedir. Ferr kutsal (tanrısal, dünya dışından), güçlü (hükümdarlık veya kahramanlık payesi veren), manevi (zekâ ve bilgelik veren), güneş (ateşli) ve aynı zamanda yaratıcıdır (Eliade, 1971, s. 14-15). Ahura Mazda tarafindan yaratılan ilahi 1şık herkese bahşedilecek bir güç değildir. Bu güç tanrı tarafından en iyi, adil, aklıyla hareket eden, doğruluk peşinde koşan, yasalara uyan, tanrılara inanan ve onun yolundan gidenlere bağışlanmıştır (Hintze, 1994 (19. Zamyâd Yaşt)). İran mitolojisinde de Ahura Mazda tarafından yaratılan ve Mithra tarafından korunan ilahi ışık hükümdarlık ile ilişkilendirilir. Nitekim Eski İran mitolojisinde ilahi ışığa sahip olan kişi hükümdarlığa da sahip olmaktadır. Yani ilahi ışı bir bakıma meşru yöneticiyi belirlemektedir. Işık tanrısı olarak kabul edilen Mithra ezelden beri var olan aydınlık ile şimdiki aydınlık arasında bir araç olarak görülmektedir. Işı̆̆ı simgeleyip aydınlığın temsilcisi olduğu için güneş anlamında da kullanılmıştır (Curtis, 2016a, s. 21). Avesta'dan anlaşıldığına göre 1ş1k ve parlaklık saçan göksel varlıklara tanrısallık atfedilmiş, kurbanlar sunulmuştur. Bu varlıklar Güneş (Darmesteter, 1883, s. 85-87 (6. Khôrshed Yaşt)), Ay (Darmesteter, 1883, s. 88-91 (7. Mâh Yaşt)) ve Sirius Ylldızıdır (Darmesteter, 1883, s. 92-109 (8. Tîr Yaşt)). Zerdüş̧’ün doğumu sırasında da kutsal 1şı teması yansıtılmaktadır. Dînkerd'e göre Zerdüşt'ün annesi onu doğurmadan önce üç gün boyunca güçlü bir 1şık saçmış ve güneş gibi parlayan o 1şık alacakaranlığ dağıtmıştır (West, 1897, s. 30 (Dîn. VII.2.56); Eliade, 1971, s. 13). Eski İran ikonografisinde yansitılan hükümdarlık ideolojisinde de parlaklık saçan bu cisimler -aşağıda görüleceği üzere- tanrısal/kutsal semboller olarak, hükümdarlarla ilişkilendirilerek rölyefler ve sikkeler üzerinde sıklıkla kullanılmıştır.

İran geleneğinin en kalıcı kavramlarından biri haline gelen ferr zamanla İran ulusal tarihinde önemli bir yere sahip olmuştur. Eski İran inan- 
c1na göre, hiçbir hükümdar o olmadan başarılı olamazdı. Kudret, ün ve şan ondan kaynaklanırdı. Meşruiyeti sembolize ederdi. Yokluğu insanların talihini olumsuz olarak değiştirirdi. Bir hükümdarın düşüşünün ya da yenilgisinin ferr'in onu terk etmesinden kaynaklandığı düşünülmekteydi (Yarshater, 2006a, s. 345). Bu anlayış İran'da kalıtsal bir hanedanlık karizmasının (kraliyet ferr'i) fikrî temelini oluşturmuştur (Gnoli, 1999, parag. 18). Böylece İran hükümdarlarının talihi olan ferr, "Kraliyet Talihi" (Kavaem Khvarenah=Ferr-i Keyânî) olarak adlandırılmıştır (Yarshater, 2006a, s. 345). Bu kavram, İran hükümdarlarının sahip olduğu iktidarın desteğini ve kaynağını belirtmektedir (Yıldırım, 2008, s. 317). Kraliyetin ön şartıdır. İran krallarının soyundan olmayanlar için erişilemez bir unsurdur (Shahbazi, 1980, s. 128). Bu kavram, İran ülkesini düşmanlardan ve kötülüklerden koruyan güç anlamına gelen (Yıldırım, 2008, s. 317-318) "İran'ın Talihi" kavramı (Airyanem Khvarenah=Ferr-i Îrânî) ile özdeşleştirilmiştir (Yarshater, 2006a, s. 345). Ferr-i İranî, hem doğmuş hem de doğacak olan İranlılara aittir ve İran'ı kötülüklerden ve düşmanlardan koruyan bir güçtür. Her statüden (askerler, din adamları, satraplar, hükümdarlar) İranlıyı kapsayan Ferr-i İranî, Ferr-i Keyânî'den daha genel ve ulusal bir kavramı temsil etmektedir (Shahbazi, 1980, s. 128, 141, 143). Bunların dışında gücü ve iktidarı ifade eden ferr-i îzedî, ferr-i yezdânî, ferr-i hudâyî, ferr-i âsumânî, ferr-i pehlevânî, ferr-i husrevî, ferr-i şahinşahî, ferr-i şehriyarî, ferr-i tâc ifadeleri de bulunmaktadır (Yıldırım, 2008, s. 318; Balc1, 2016, s. 371 (dn.378)). Kısacası ferr, İran ulusal birliğinin bir sembolüdür (Malandra, 1983, s. 88).

Ferr'in İranlılara geçmesinin Avesta ve Eski İran edebiyatında anılan Kavi (Keyânî) hanedanlığı vasıtasıyla olduğuna inanılmaktadır. Nitekim Avesta Yaştlardan yola çıkarak T. Daryaee, İran'ın eski hanedanlıklarından Keyânî hanedanlığı hükümdarlarının, İran toprakları üzerinde hâkim olmak isteyen düşmanlara karşı ferr'i kazanmak için tanrılara sunular yaptığını, böylece tanrıların kararıyla ferr'in İranlılara bahşedildiğini, ancak bu yetkinin kalıcı olmadığını, zira gerektiğinde İranlı hükümdarlardan veya İranlı olmayan şeytanî karakterlerden geri alındığını ifade etmektedir (Daryaee vd., 2017, s. 165). Ferr'in geri alınmasının nedeni, hükümdarın dini geleneklerden ve kurallardan yani dindarlıktan uzaklaşması olarak açıklanmaktadır. Bir nevi hükümdarlıktan azledilme anlamına gelen bu durumun, seçilmiş hükümdarın tanrının yolundan ayrılması, yalana başvurup doğruluktan vazgeçmesi, tanrılara yüz çevirip benlik duygusuna kapılması durumunda gerçekleşeceğine inanılmaktaydı (Curtis, 2016a, s. 21). Ferr, 
birinden ayrıldığında veya kaçtığında genellikle hızlı hareket edebilen bir hayvan şeklinde tezahür edilmiştir. Bu durum ferr'in kişileşmesi olarak kabul edilmektedir (Shahbazi, 1980, s. 128). Avesta'da, Yima'nın (Cemşid) hükümdarlığının anlatıldığı bölümde, tanrı tarafından hükümdar olarak yetkilendirilen Yima'nın yalana yenik düştüğü (doğru yoldan saptığı) ve ferr'in ondan ayrılıp tanrı Mithra'ya geri döndüğ̈̈; bir şahin (varegna) şekline bürünüp Vouroukaša Gölü'nde tanrı Apam Napāt'ın korumasına girdiği anlatılmaktadır (Hintze, 1994 (19. Zamyâd Yaşt (31-53); Yarshater, 2006a, s. 345). Burada geçen varegna kelimesinin, şahin gibi yırtıcı bir kuşu (veya simurg kuşunu) tanımladığı düşünülmektedir (Yıldırım, 2008, s. 318). Nitekim İran ikonografisinde varegna'nın, ferr'in taşıyıcısı olduğuna dair göstergeler de bulunmaktadır (Soudavar, 2016, parag. 7; Curtis, 2016b, s. 181, Res. 31b). Böylece Cemşid hikâyesinde ferr'in üç önemli yönünün altı çizilmektedir: “a) Kalıcı olmadığı ve kaybolabileceği. b) Etkin olmadığı zaman su altında uyku halinde olduğu. c) Birinin ona sahip olabilmesi için su altından çıkması gerektiği.” (Soudavar, 2016, parag. 2).

Yukarıda verilen Yima örneğinde olduğu gibi ferr, kötülüğe sapmış hükümdarlardan ayrılmaktaydı. Anlaşılan o ki ferr, dünyada kötülük üstünlügü elde ettiğinde meşru bir hükümdarın tekrar ortaya çıkacağı zamana kadar kozmik deniz Vouroukaša'ya sığınmaktaydı (Malandra, 1983, s. 88). Söz konusu anlayış, Eski İran tarihi boyunca meşruiyet bağlamında kullanılan en önemli unsur haline gelmiştir. Nitekim bu anlayış yazılı metinlerde işlendiği gibi Eski İran ikonografisinde de yer edinmiştir. Bunu ifade edebilmek için bir takım ilahi anlamlar yüklenen semboller, işaretler kullanılmış ve bu işaretler hükümdarın yasallığını kanıtlayan bir araç haline gelmiştir (Daryaee vd., 2017, s. 165). Avesta metinlerindeki bu anlayışın tarihi süreçte İran edebiyatına da yansıdığını söyleyebiliriz. Nitekim buradaki birçok hikâyeyi ve temayı Şahnâme geleneğinde de görmek mümkündür. Mesela Şahnâme'nin birçok satırında İran hükümdarları için “yeryüzü padişahı" ifadesi kullanılır. Yine Şahnâme'de bütün dünyanın hükümdarı olarak dünyayı yönetme gücünün tanrı tarafindan Feridun ve oğullarına verildiği ifade edilmektedir (Firdevsî, 2009, s. 85-102). Avesta' daki Yima hikâyesi de Firdevsî'nin Şahnâme'sinde Cemşid hikâyesi olarak geçmektedir. Şahnâme' de Cemşid'in tanrılar tarafından tahta çıkmaya layık görüldüğü ancak böbürlenerek kendinden başka kimseyi görmez hale gelince “tanrıya karşı benlik davasına girince" tanrının ferr'inin Cemşid'den ayrıldığı anlatılmaktadır (Firdevsî, 2009, s. 69-78). 
Pers dönemine ait Persepolis'teki sırlı tuğla panel üzerindeki sahne (Schmidt, 1953, s. 91, Res. 35) (MÖ 6-5. yüzyıl) Avesta'daki Yima hikâyesinin adeta ikonografiye yansımış halidir diyebiliriz. Bu sahnede ferr, suyun altında dairesel bir kabın içindedir ve sudan yükselerek nilüfere, oradan da bir ayçiçeğine dönüşmektedir. Ayçiçeği Mithra'nın, nilüfer ise su tanrılarının sembolü olarak bilinmektedir. Bu sahnede yer alan inci motifi de daha sonra bir ferr sembolü haline gelmiştir. Güneş’te yaşayan Mithra gündüzleri, sularda yaşayan Apam Napat (Anahita) ise gece vakti bu işi idare etmektedir. Benzer durum Sâsânî hükümdarı III. Şâpur'un (383-388) Tak-1 Bostan'daki (Kirmanşah) rölyefinde de işlenmiştir. Burada Ahura Mazda, hükümdarı yönetim için yetkilendirirken Mithra da büyük bir nilüferin üzerinde durmaktadır. Bu sahnede Romalılara karşı kazanılan zaferin suyun altından nilüfer vasıtasıyla yüzeye çıkarılan ve Mithra tarafindan bahşedilen İran ferr'inden kaynaklandığı sembolize edilmektedir (Soudavar, 2016, parag. 13).

\section{Pers Kaynaklarında Tanrısal Seçim İdeolojisi}

Pers yazıtları dünyayı, insanoğlunu ve dünya üzerindeki diğer canlıları, insanların rahat etmesi için her türlü imkânı Ahura Mazda'nın yarattı̆̆ını ifade etmektedir: "Büyük tanrı Ahura Mazda bu yeryüzünü yaratt1, cenneti yaratt1, insanoğlunu yaratt1, insanlar için refahı yarattı." (Kent, 1950, s. 138, 148, 156 (XPa §1; $\left.\left.\mathrm{A}^{3} \mathrm{~Pa} \S 1 ; \mathrm{DNa} \S 1\right)\right)$. Pers hükümdarlık ideolojisine göre, Ahura Mazda nasıl ki kâinatta düzeni sağladıysa onun seçtiği hükümdarın görevi de dünyadaki düzeni sağlamaktır. Zira Pers yazıtlarında dünyanın başlangıcında kaos ve kargaşanın hâkim olduğu, düzenin bozulduğu ifade edilerek Ahura Mazda'nın yardım ve inayetiyle hükümdarın insanları kurtardığı, düzeni yeniden sağladığı bildirilmektedir (Kent, 1950, s. 138 (DNa §4)). Pers kral yazıtlarının genelinde hükümdarlar, tanrının yardımı ve isteği ile yönetme erkinin kendilerine verildiğini açıkça bildirilmektedir.

Pers hükümdarlarının tanrı ile olan bağlantıları, Pers ikonografisinde de birtakım sembollerle ifade edilmiştir. Bu sembollerden en dikkat çekeni, ikonografik sahnelerin en üstünde tasvir edilen, kanatlı disk ve diskten yükselen figürdür. Bu sembolün tanımı ve işlevi konusunda birçok tartı̧̧ma bulunmaktadır (Root, 1979, s. 169, 171). Bu noktada sembolün Ahura Mazda'yı ve hükümdarın Fravahr/Fravaši'sini temsil ettiği ileri sürülür 
(Alram vd., 2007, s. 28-29). Fravahr/Fravaši, Pehlevicede dünyevi varlikların koruyucu ruhu olarak ifade edilmektedir (Nyberg, 1974, s. 77). Ancak Avesta'da fravašinin dişi olmasından dolayı, söz konusu kelimenin kralın ruhunu ifade etmesinin çelişki arz etmektedir (Alram, vd., 2007, s. 29). Curtis, Perslerin kullandığı bu sembolün Misır ve Asur medeniyetlerinden uyarlandığını, İran tarihinde ilk olarak Persler tarafindan kullanılan bu sembolün, Ahura Mazda'yı ya da hükümdarın ferr'ini (Ferr-i Keyânî) gösterdiğini ifade etmektedir (Curtis, 2016b, s. 179). A. Sh. Shahbazi bu sembolün iki kavramı simgelediğini söylemektedir. Buna göre kanatlı disk, Ferr-i İranî'yi sembolize ederken kanatlı adam Ferr-i Keyânî'yi tanımlamaktadır (Shahbazi, 1980, s. 121). Sembol, bir kartalın veya benzeri bir kuşun kanatları ile bir kralın birleşimi gibi görünmektedir. Shahbazi, İran'ın krallık kavramının, "kuşların kralı" ile bağlantılı olmasının rastlantı olmadığını düşünmektedir. Ayrıca bu durumu Avesta'daki Varegna (şahin) ile ilişkilendirerek bunun İranlıların dini ve milli geleneklerine dayandığını belirtmektedir (Shahbazi, 1980, s. 137-138).

Perslerin Ahura Mazda'yı diğer tanrılara üstün tuttuğu da ifade edilebilir. $\mathrm{Bu}$ durumun I. Dareios ile başladığ düşünülmektedir. Dareios'un oluşturduğu Pers hükümdarlık ideolojisine göre bu tanrının her yerde mevcut ve her şeye gücü yeten olması gerekmekteydi. Avesta'da karşılaşılan diğer tanrılar Mithra ve Apam Napat, ferr'i bağışlayan ve koruyan tanrılardır. Ahura Mazda ise ferr' in yaratıcısı olarak ilan edilmiştir (Soudavar, 2016, parag. 5,9).

Pers ikonografisinde kanatlı disk figürünün altında genellikle bir kral figürü yer almaktadır. Bunun yanında her iki figüre halka/yüzük, ateş sunağı ve göksel cisimler gibi birtakım farklı semboller de eşlik etmektedir. Bu semboller Pers hükümdarlık ideolojisi bağlamında tanrı ve hükümdar ilişkisi açısından birbirleriyle ilişkilendirilir. Behistun Rölyefinde Pers hükümdar1 ve tanrı aynı mekânı paylaşmaktadır. Bunun yanında fiziksel olarak da aynı biçime sahip oldukları dikkat çekmektedir. Pers hükümdarı bu sahnelerde adeta kanatlı diskten yükselen figürün bir yansıması gibidir. Her iki figür de aynı saç ve sakal tipine, benzer taca ve giysiye sahiptir (Llewellyn-Jones, 2017, s. 79). Aynı ikonografi Nakş-i Rüstem'deki kral mezarlarında da işlenmiştir. Burada da hükümdar ile ilahi varlık birbirlerine sağ elleri ile selam vermektedir. Selamlama/kutsama denilen bu hareket bir iyi niyet göstergesi olarak yorumlanmaktadır ve Yeni Asur döneminde de 
bilinen bir durumdur (Garrison, 2011, s. 39; Root, 1979, s. 174-176). İlahi varlığın sol elinde kraliyet gücünü simgeleyen halka/yüzük bulunmaktadır. Nakş-i Rüstem'de ayrıca kürsü ve ateş sunağı motifleri işlenmiştir. Sahnedeki bütün figürler ve semboller, tahtı anımsatan bir yapının üzerine yerleştirilmiştir. Tahtın altındaysa, Pers egemenliğinde bulunan halklar, kralın tahtını taşır vaziyette tasvir edilmiştir (Kuhrt, 2019, s. 395-396). Bu ikonografilerde karşılaşılan kanatlı diskteki figürün krala sunmuş olduğu halka/yüzük, hükümdarlığa atanmanın bir sembolü olarak yorumlanmaktadır. E. Ehrenberg aynı zamanda bunun, ilahi ışık olan ferr'in "kozmik özü" olduğu ifade eder ve halkanın/yüzüğün dairesel yapısının dünyayı temsil ediyor olabileceğinden hareketle tanrının, dünyaya hükmetme yetkisini kendi seçtiği hükümdara verdiği anlamının çıkarılabileceğini belirtmektedir (Ehrenberg, 2017, parag. 4-5).

Tanrı ile hükümdar arasındaki bu münasebet, Pers mühürleri üzerinde de tasvir edilmiştir. Bu bakımdan Persepolis Tahkimat (Sur) Mühürleri (PFS) Pers hükümdarlık ideolojisinin ilahi bağlantılarını yansıtması bakımından dikkate değerdir. Mühürlerde, rölyeflerden farklı olarak mitolojik hayvanlar ve palmiye ağacı motifleri de yer almaktadır. Mühürlerde Pers kraliyet kaftanı içindeki figür, sağında ve solunda bulunan iki mitolojik yaratığ boynuzlarından tutmuş vaziyette tasvir edilmiştir. Sahnenin merkezinde bulunan bu tasvirin hemen üzerinde kanatlı disk, figürün sağında ve solunda palmiye ağaçları ve yazıtlar yer almaktadır (Garrison, vd., 2001, s. 18; Finn, 2011, s. 229-230). Finn, bu tarz kullanımın Pers öncesi dönemde kutsallığın bir temsili olarak yorumlandığını, erken Pers döneminde de bu imgenin hükümdarın ilahi seçimini yansıtmak için kullanıldığını ifade etmektedir (Finn, 2011, s. 231). Mühürlerde ayrıca hükümdarın hayvanlarla mücadele sahnelerinin, hükümdarın sadece insanların değil yeryüzündeki diğer canlıların da hâkimi olduğu ideolojisini yansıtmak için kullanıldığ düşünülmektedir (Kaptan, 2018, s. 261). Garrison, "kralın aynası" olarak nitelendirilen mühürlere Pers ideolojisi bağlamında "panoptik/emperyal" adını verdiği bir teori ile açıklama getirmektedir. Buna göre mührün merkezinde hükümdar, hükümdarın tam üzerinde kanatlı disk figürü yer almaktadır. Mühür tam ortasından dikey bir çizgiyle ayrılırsa, her iki tarafta da sırasıyla aynı görüntü sahnelenir. Garrison bunun, kişide bir süreklilik, devamlılık hissi uyandırdığını söylemektedir. Aynı zamanda tanrı ve hükümdar arasındaki ilişki ile de bu durumun yinelendiğini ifade etmektedir (Garrison, 2011, s. 62-64. Ayrica bknz. Briant, 2002, s. 217-219; Finn, 2011, s. 232-233). 
İkonografideki bu sembolizm, kâinatın hükümdarı olan tanrı ile onun dünyadaki vekili olan hükümdar arasındaki bağlantıyı vurgulamaktadır. Burada verilen mesaj son derece açıktır: "Hükümdara karş1 gelmek, kozmik ve ahlaki düzene karşı gelmek" demektir. Bu tarz bir davranış Ahura Mazda'yı inkâr etmekle, yani dinsizlikle eş tutulmuştur (Kuhrt, 2019, s. 400). Böylece tanrının isteği hükümdarın gücüyle birleştirilmiştir. Pers hükümdarı, tanrı korumasına mazhar olarak yönetimini yasallaştırmıştır (Allen, 2005, s. 122).

Pers krallık ideolojisindeki tanrısal yetki, böylece Pers hükümdarlarını evrensel kral haline getirmiştir. Tanrısal yetkiyle donatılan Pers hükümdarı, artık dünyanın ve dünya üzerinde yaşayan canlıların (insanların ve hayvanların) egemeni olarak yükselmiştir. Bunu da tanrıların izni ile gerçekleştirmiştir. Kyros Silindirinde tanrı Marduk'un desteğiyle Babil'i ele geçirdiğini ilan eden Büyük Kyros, kendisini “dünya kralı”, Sümer ve Akkad'ın kralı, dört iklim kralı" olarak nitelendirmiştir (Brosius, 2006b, s. 10-11). I. Dareios ise hâkimiyeti altında bulunan memleketleri listeler halinde sıralamıştır: "Kral Dareios der ki: ... Ahura Mazda'nın isteği ile onların kralı oldum; Persia, Susa, Babil, Asur, Arabia, Misir, denizde olan topraklar, Sparda, Ionia, [Media], Armenia, Kappadokia, Parthia, Drangiana, Aria, Khorasmia, Baktria, Sogdia, Ga(n)dara, İskitya, Sattagydia, Arakhosia, Makai; hepsi toplam yirmi üç ülke.” (Kent, 1950, s. 119 (DB. I. §6)). Bu gibi listelere I. Dareios'tan sonraki Pers hükümdarlarına ait yazıtlarda da rastlanmaktadır. İmparatorluğun himayesindeki memleketlerin belirtildiği egemenlik listelerine zaman zaman Hindistan gibi Asya coğrafyasından farklı bölgeler de dâhil edilmiştir (Kent, 1950, s. 136, 138 (DPe §2; DNa $\S 3)$ ). Pers hükümdarlarının bu listeleri vermesindeki amaç, kendilerinin ne denli geniş nüfuza ve topraklara sahip olduklarını ilan etmek olmalıdır. Dikkatli bir şekilde bakıldığında kitabelerde adı geçen bölgelerin, zamanın yaşam merkezlerine işaret ettiği fark edilmektedir. Pers hükümdarları başta İran coğrafyası olmak üzere Mezopotamya, Mısır, Anadolu, Avrupa ve kısmen Indus gibi Pers merkezine yakın ve uzak bilinen dünyanın mamur coğrafyalarına sahip olduklarını ilan etmiştir (Kent, 1950, s. 138 (DNa §4)). Böylece Pers hükümdarı açık bir şekilde her yerin kralı, dünya kralı olduğunu bildirmiştir. Artık Pers himayesinde olanlar Pers kural ve kanunlarına tâbi olmuştur. Onlar Pers hükümdarının emirlerine uyan hizmetkârlar haline gelmiştir (Kent, 1950, s. 119 (DB. I. §7-8)). Persepolis Apadanasının merdivenlerine nakşedilen, yılın belirli bir zamanında Pers 
hükümdarının evrensel durumunu kabul edip ona itaatlerini sunmak üzere Persepolis'e gelen halkların tasvirleri; Nakş-i Rüstem'de hükümdarın tahtını taşıyan halklar rölyefi; Dareios'un Susa heykeli üzerindeki Perslere bağlı halkları tasvir eden kabartmalar da Pers hükümdarının evrensel durumunun yansitılmasına hizmet eden diğer araçlardır (Kuhrt, 2019, s. 396). I. Dareios'un Susa heykeli üzerinde tasvir edilen halkların avuç içleri açık ve yukarı bakar vaziyette, kollarının öne ve yukarı doğru uzatılmış halde tasvir edilmesi hükümdarı taşıma ve destekleme anlamına gelmektedir (Ehrenberg, 2017, parag. 3). Bu bakımdan Susa heykelinin anlamsal olarak tahtı taşıyan halklar rölyefleri ile benzer olduğu söylenebilir (Colburn, 2014, s. 787).

Pers dönemine son vermeden önce Yunan kaynaklarında geçen bir duruma da kısaca değinmek gerekmektedir. Antik Yunan kaynaklarında Pers hükümdarlarının tanrılığına dair bir düşünce olduğu anlaşılmaktadır. Onları bu düşünceye sevk eden sebep Pers hükümdarlarının huzuruna çıkan kişilerin yaptığı bir selamlama hareketidir (Garrison, 2011, s. 24). Yunan

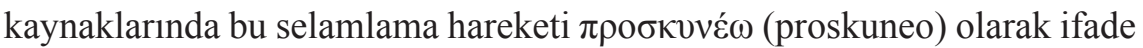
edilmektedir (Hdt. VII. 136; Ksen. Anab. I.8.21; Plut. Them. 27.4). Kelime aslen "tanrılara bir öpücük gönderme" anlamına gelmektedir (Choksy, 1990, s. 202). Herodotos'un ifadesine göre Pers hükümdarının karşısına çıkan kişinin hükümdara secde edip ( $\pi \rho 0 \sigma \kappa v ́ v \eta \sigma ı)$ ) onun ayaklarının dibinde yeri öpmesi gerekirdi (Hdt. VII. 136). Hükümdarın huzuruna girerken karşısında dizlerini ve vücudunu hafifçe öne eğip eliyle de bir öpücük göndermek şeklinde yapılan bu hareket Pers hükümdarlarının ilahi statüsünün değil, hükümdarın yüceliğinin tanınmasının ve bir itaat göstergesinin ifadesidir $^{3}$ (Garrison, 2011, s. 24-25; Frye, 1972, s. 103; Briant, 2002, s. 223; ayrıca bknz. Wiesehöfer, 2003, s. 57; Garthwaite, 2011, s. 52). Zira Herodotos Kserkses'in Yunanistan seferi sirasinda Kserkses-Artabanos konuşmasında geçen diyaloglarda Kserkses'i bir insan olarak tanımlamaktadır (Hdt. VII.46-47). Bunun yanında savaşta başarılı olabilmek için Kserkses'in tanrılara dua edelim diyerek askerlerine telkinde bulunduğunu ifade etmektedir (Hdt. VII.53). Bu ifadeler aslında Herodotos'un Pers hükümdarını tanrı olarak değil bir insan olarak gördüğü anlamına gelmektedir. Kaldı ki Herodotos, Perslerin kurucu kralı Büyük Kyros’un soyu hak-

Bu hareket hürmet selamlaması olarak Sâsânîler ve erken İslami döneme kadar devam etmiştir (Choksy, 1990, s. 202). 
kında bilgi verirken onun tanrısal olduğuna dair bir ifade kullanmamasının yanında annesi ve babasının kimliklerini de açıkça ifade etmektedir. (Hdt. III.75, VII.11; ayrica bknz. FGrHist II A 90 F66 (3-7) 'Nikolaos' = Const. Proph. de Insid. p. 23. 23). Bunun yanında Pers yazıtlarında da hükümdarlar soylarını bir tanrıya dayandırmamıştır. Perslerin kurucusu Büyük Kyros Babil'i ele geçirdikten sonra yazdırdığı kendi adıyla anılan silindir mühründe soyunu Anşan krallarına dayandırarak kutsal bir davet üzerine (Marduk'un yardımıyla) gelip Babil Kralı Nabonidus'u mağlup ettiğini, ardından Babil Kralı olduğunu bildirmektedir (Brosius, 2006b, s. 10-12). Bir başka yazıtında ise kendisini bir Akhaimenid olarak ifade etmiştir (Kent, 1950, s. 116 (CMa, b)). Sonraki Pers hükümdarları da soylarının ilk basamağı olarak kral Akhaimeniš'i işaret etmektedir ve kendilerini "bir Aryan, Aryan soyundan" olarak nitelendirmiştir (Kent, 1950, s. 119, 138, 148 vd (DB I. §2, 5, DNa §2-3, XPa §2, 4 vd)). Yazıtlarda geçen "Aryan soyundan" ifadesi Eski Farsça'da Ariya ciça (Avesta'da čitra, Pehlevicede čihr) şeklinde ifade edilmiştir (Nyberg, 1974, s. 55; Panaino, 2009, s. 236; Daryaee, 2002, s. 41).

\section{Parth Dönemi Kaynaklarında Tanrısal Seçim İdeolojisi}

Parth dönemine tarihlendirilen rölyeflerde ve bazı sikkelerde iktidarın kaynağına dair göstergeler bulmak mümkündür. Bu konuda Elymais bölgesindeki Tang-i Sarvak'taki bir rölyef dikkat çekicidir. Elymais, Güneybatı İran'da (Huzistan, Susa) MÖ 2. yüzyıldan MS 3. yüzyılın başlarına kadar bazen bağımsız bazen Parthlara bağlı hüküm sürmüş bir krallıktır (Hansman, 2011, parag. 12). Elymais Krallı̆̆ 1 , I. Kamnaskires'in çabalarıla MÖ 147'de bağımsızlığını elde etmiştir. Parth Kralı I. Mithradates (MÖ 171139/8) zamanında da Parthlara bağlanmıştır (Curtis, 2007, s. 10). Bu bölgede bulunan Tang-i Sarvak’ta sedir biçiminde bir taht üzerinde uzanmış bir hükümdar sahnelenmektedir. Sedirin ayakları kartal olduğu düşünülen bir kuş formunda tasvir edilmiştir. (Henning, 1952, s. 155). Burada uzanmış vaziyetteki kralın elinde halka/yüzük bulunmaktadır (Sivrioğlu, 2018, s. 52). Hükümdarın önünde iki figür daha tasvir edilmiştir. Bu figürlerin tanrıları sembolize edip etmediğine dair tartışmalar mevcuttur (Haerinck, 2005, parag. 7; tanrısal seçimi sembolize ettiğine dair bknz. Schlumberger, 2007, s. 1043). 
Elymais'taki Khung-i Nevruzi/Azhdar (Huzistan, İzeh) rölyefinde de halka/ yüzük motifi ile karşılaşılmaktadır. Khung-i Nevruzi'deki sahnenin Parth Kralı tarafindan Elymais Krallığına bir kralın atanmasının tasvir edildiği düşünülür. (Brosius, 2006a, s. 131, Res. 29). Muhtemelen buradaki Parth Kralı I. Mithradates'tir (Schlumberger, 2007, s. 1043). ${ }^{4}$ Sahnede iki şahin motifi yer almaktadır. Şahinlerden biri sahnede ayakta duran yöneticiye atanma halkası/yüzüğünü götürmektedir. Diğer şahin ise atının üzerinde duran hükümdara kurdeleli bir halka/yüzük ulaştırmaktadır (Soudavar, 2003, s. 22). IV. Artabanos'un bir sikkesinde de hükümdarın tanrıdan bir hükümdarlık sembolü alması tasvir edilmiştir (Curtis, 2007, s. 14). Bunun yanında bazı araştırmacılar tarafından Parth sikkelerinin arka yüzünde bir omphalos üzerinde (daha sonra taht) oturan, eline yay tutan erkek figür, efsanevî veya mitolojik bir İran kahramanı olan Areş ile bağdaşlaştırılmaktadır. Oturur vaziyetteki bu okçu figür, hükümdarlık otoritesini ifade etmek için kullanılmıştır (Lerner, 2017, s. 9; Areş hakkında bknz. Yıldırım, 2008, s. 66-67). Tang-i Sarvak ve Khung-i Nevruzi'deki ikonografik sahnelerdeki halka/yüzük ve kuş motiflerinin Pers dönemindeki tanrısal yetkiyi ifade eden motiflerle benzerliği dikkat çekmektedir.

MS 1. yüzyıldan sonraki Parth sikke ikonografisinde hükümdar ve tanr1 münasebetini yansıtan semboller yer almaya başlamıştır. Ferr ile ilgili olan bu semboller diadem, yıldız, hilal ve yırtıcı bir kuş motifidir (Curtis, 2016b, s. 182). Başa sarılan ince şerit olan diadem özellikle Hellenistik krallar tarafından sıklıkla kullanılmış ve zamanla kraliyet simgesi haline gelmiştir (Uygun, 2019, s. 266; Calmeyer, 2011, parag. 4). IV. Phraates'in sikkesinde, gagasında kraliyet diademi taşıyan kartal figürü ile hilal içinde yıldız sembolü tasvir edilmiştir. Phraatekes'in drahmilerinde hilal içinde y1ldız sembolü bulunur (semboller için bknz. Curtis, 2016b, s. 184). II. Vonenes'in ve IV. Artabanos'un sikkelerinde altı uçlu yıldız ve güneş sembolü görülmektedir (Gariboldi, 2004b, s. 38-39). Yıldız motifinin hükümdar ile tanrıça Anahita'nın bağlantısını gösteriyor olabileceği düşünülmektedir. I. Vologases'in bir gümüş tetradrahmisinde Parth hükümdarı, tanrıça Anahita'dan diadem alırken tasvir edilmiştir (Curtis, 2016b, s. 183). Parth sikkelerinde ferr'in bir başka sembolü, hükümdarın alnında bulunan nokta şeklindeki siğil motifidir. Bu işaret zamanla Parth hanedanlığının ayırt

Burada sahnedeki kral Parth Kralını değil Seleukos Kralı II. Demetrius Nikator'u tasvir ediyor olabilir (Invernizzi, 1998'den aktaran Brosius, 2006a, s. 131). 
edici bir özelliği haline gelmiş ve bu ikonografi Parthların hanedanlık kanının güvencesi olmuştur. Özellikle Roma ile yapılan Kharrae (Harran) Savaşı'ndan (MÖ 53) sonraki sikkelerin bütün tiplerinde hükümdarın kaş1 üzerinde siğil motifi tasvir edilmiştir (Sellwood, 2006, s. 290, levha 4-5).

Parth sikkelerinde tanrısal seçimi yansıtan bu durumun yanında Parth hükümdarlarının doğrudan tanrı ilan edildiğini düşündüren ifadelerin bulunması, Parthlarda tanrı-kral ideolojisi üzerine tartı̧̧maları beraberinde getirmiştir. Nitekim II. Arsakes'in bir gümüş drahmisinde BA $\Sigma Y \Lambda E \Omega \Sigma \Theta E O Y$ AP $\Sigma$ AKOY (basileos theou Arsakou/tanrı kral Arsakes) ifadesi bulunmak-

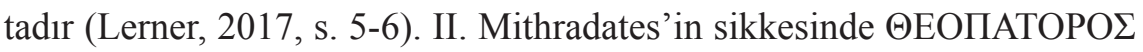
(theopatoros/babas1 bir tanr1) lejant1 yer alır (Curtis, 2007, s. 9-10). II. Mithradates, III. Mithradates, II. Orodes ve diğer bazı Parth hükümdarlar1nın sikkelerinde ise ЕПІФАNOY $\Sigma$ (epiphanous/(tanrı) tezahürü) ibarelerine rastlanmaktadır (Sellwood, 2006, s. 285). MS 4. yüzyılın Romalı yazarı A. Marcellinus da Parth hükümdarlarının tanrısallığına dair atıf yapmaktadır. Marcellinus, Parth hükümdarlarının kurucu Arsakes'ten sonra halk tarafindan ilahlaştırıldığını, ay ve güneşin kardeşleri olarak anıldığını, bundan dolayı Arsakes'in soyundan gelen birinin hükümdarlık için tercih edildiğini ifade etmektedir (Amm. XXIII.VI.5-6).

Sikkelerde karşılaşılan bu tarz örnekleri çoğaltmak mümkündür. Ancak Parth sikkelerinde görülen bu Yunanca ibarelerin Hellenistik kültürün, yani Seleukosların tesiri olduğu ve bu durumun siyasi bir propaganda aracı olarak kullanıldığı düşünülür. Bu durum Hellenistik dönemde ilk defa Büyük İskender'in Mısır'da Amon'un oğlu olarak selamlanmasından sonra görülmüş, Ptolemaioslar ve Seleukoslarda da tanrı-kral düşüncesi devam etmiş̧ir (Diod. XVII.77.5; Arr. An. IV.7.4; Güzel, 2017; Yurtsever, 2015, s. 8-10). Bu düşünceden hareketle Gariboldi, sikkelerde geçen theopator ifadesinin Ortodoks Zerdüşt dini ile çeliştiğini, kralın bir tanrı değil, tanrının bir temsilcisi gibi düşünülebileceğini ifade etmektedir (Gariboldi, 2004a, s. 368-269, 376). Lerner, bu durumun Parth hükümdarlarının tanrı olduğu anlamına gelmediğini, halkın ve seleflerin I. Arsakes'e tanrı gibi sayg1 duydukları anlamına geldiğini söylemektedir (Lerner, 2017, s. 5-6). Frye (1964, s. 45-46) ise İranlıların yaşayan hükümdarlarının tanrı olduğuna inanmadığını, sikkeler üzerindeki Yunanca elkâbların Parth devletinde yaşayan Hellenik yerleşimciler için tasarlandığını düşünmektedir. Ona göre tanrısallık içeren unvanlar hükümdarın kişiliğinden ziyade, hükümdarlık 
makamına yöneliktir. Nitekim erken Parth dönemi sikkelerinde yer alan Yunanca lejant Parthların son iki yüzyılında İranlı köklere dönüşle birlikte ortadan kaybolmuş ve sikkelerde Parthça lejantlar hâkim olmuştur (Wiesehöfer, 2003, s. 189, 197).

\section{Sâsânî Kaynaklarında Tanrısal Seçim İdeolojisi}

Sâsânî dönemine ait eserlerde hâkimiyetin kaynağı, tanrısal destek olarak yansıtılmıştır. Bunun yanında Parthlarda olduğu gibi hükümdarın tanrısallığına dair tartışmalar da mevcuttur. Karnâme-i Ardeşîr-i Bâbekân'da Ferr-i Keyânî'nin Sâsân'ın soyundan olan Ardeşir'e bahşedildiği propagandası yapılmaktadır. Karnâme'de Pâpag'ın (Bâbek) üç gece boyunca rüya gördügü, ilk gece rüyada kutsal bir ateşin Sâsân'ın başında bir güneş gibi parladığ 1 ve adeta tüm dünyayı aydınlattığı; ikinci gece beyaz bir filin üzerinde oturan Sâsân'a etrafindakilerin saygı duyduğu; son gece ise kutsal ateşler Adar Farnbag, Adar Guşnasp ve Adar Burzin'in Sâsân'ın evine ve tüm dünyaya 1şı saçtı̆̆ını gördüğü anlatılmaktadır. Pâpag bu rüyalar1, rüya yorumcularına anlatmış, yorumcular da Sâsân'ın soyundan birinin bu dünyanın egemeni olacağını bildirmiştir (Sanjana, 1896 (Kârnâme Ardeşîr-i Bâbekân, I.8-21, IV. 15, VII. 1)). Karnâme’ye göre Ferr-i Keyânî, Ardeşir'e bir koç şeklinde zuhur etmiş ve koç, Parth hükümdarı IV. Artabanos ile mücadelesinde Ardeşir'in yanından ayrılmamıştır (Soudavar, 2003, s. 20-21; Cereti, 2011, parag. 4). Benzer bir hikâye Şahnâme'ye de yansımıştır. Şahnâme'de Ardeşir'in arkasından gelen bir dağ koyununun, Ardeşir'e ulaşan tanrısal bir destek, ilahi bir güç olduğu vurgusu yapılmaktadır (Firdevsî, 2020, s. 469). Bu noktada, Pers dönemindeki kanatlı adam sembolünün yerini Sâsânî döneminde kanatlı koç motifinin aldığı düşünülmektedir. Burada koç, Ferr-i Keyânî’yi temsil etmektedir. Kraliyetle bağlantısı ise koçun boynuna bağlanan uzun kurdeleli bir taçla sağlanmıştır (Shahbazi, 1980, s. 140, Res. 10).

Ardeşir'in oğlu I. Şâpur dönemine ait yazıtlarda da hükümdar ve tanrı arasındaki ilişkiler ve tanrısal koruma ve destek ideolojisi yansıtılmaktadır. Bilindiği üzere I. Şâpur döneminde Roma ile çetin mücadeleler yaşanmışt1. Bu savaşlar genel olarak Sâsânîlerin üstünlügü ile sonuçlanmış, hatta Edessa Savaşı'nda (259/260) Roma imparatoru Valerianus esir alınmıştı (Zerrinkûb vd., 2019, s. 49-52). Bu başarılar Nakş-i Rüstem'e hem rölyef hem yazıt olarak kaydedilmiştir. Nakş-i Rüstem'deki Kâbe-i Zerdüşt yazı- 
tında I. Şâpur, bu büyük zaferlerin tanrının desteği ve koruması ile gerçekleştiğini bildirmektedir (ŠKZZ 31-32: http://parthiansources.com/texts/skz/ skz-translation/). Arap tarihçilerin eserlerinde de İran'daki tanrısal seçim anlayışına dair referanslar bulmak mümkündür. Taberî tarihinde Parth hükümdarı IV. Artabanos ile Ardeşir'in mektuplaşmalarından bahsedilirken, Ardeşir'in tanrıların bahşettiği güç ve kuvvetle hükümdar olduğunu söylediği ifade edilmektedir (Taberî, 1973, s. 194).

Sâsânî ikonografisi üzerinden de tanrı ve hükümdar münasebetini figür ve semboller vasıtasıyla takip etmek mümkündür. Bu bakımdan Sâsânî rölyefleri (Nakş-i Rüstem, Nakş-i Recep ve Tak-1 Bostan) ve sikkeleri önemli detaylar sunmaktadır.

Sâsânî rölyeflerinde hükümdarların atanma sahnelerinin işlendiği tasvirler, hükümdar ile tanrı arasında olan bağlantıyı yansıtmaktadır. Sâsânî öncesi İran ikonografisinde karşılaşılan, ilahi varlığın hükümdara halka/yüzük sunma teması Sâsânî döneminde de devam etmiştir. Sâsânî ikonografisinde yüzüğe diademe benzeyen bir kurdele eklenmiştir (Sivrioğlu, 2018, s. 52). Bu kurdelenin Parth döneminde kullanılan diademin yerine kullanılmas1, Sâsânîlerle birlikte yeni bir hanedanlığın yükselişini ifade etmektedir. İlk kez I. Ardeşir tarafından kullanılan kurdeleye I. Şâpur'un Roma galibiyetlerinden sonra dast-ar (zafer veren) anlamı yüklenmiştir (Soudavar, 2016, parag. 11). Nakş-i Rüstem'e yaptırılan kabartmalardan I. Ardeşir'in tanrı tarafından hükümdarlığa atanmasının sahnelendiği rölyefte, Ardeşir, Ahura Mazda'dan hükümdarlık sembolü olan bir halka/yüzük alırken tasvir edilmiştir. Buradaki sahnede solda bulunan Ardeşir, Parth hükümdarı IV. Artabanos'u atının ayakları ile çiğnemektedir. Aynı şekilde karşısındaki Ahura Mazda da kötü ruh Ahrimen'i (Ehrimen) atının ayaklarına sermiş vaziyettedir. Ahura Mazda, sağ eli ile iktidar halkasını/yüzüğünü Ardeşir'e uzatır. Tanrının sol elinde ise bir asa (barsom) bulunmaktadır (Luschey, 2011, parag. 7; Canepa, 2010, s. 576, Res. 12; Beyânî, 2020, s. 33). Burada Sâsânîlerin Nakş-i Rüstem bölgesini kullanmaları dikkat çekmektedir. Zira Persler için de burası kral mezarları, rölyefler ve yazıtların bulunduğu özel bir bölge idi. Bu konuda M. P. Canepa, I. Ardeşir ve I. Şâpur'un yaptırmış olduğu rölyefler vasıtasıyla Pers kalıntıları arasında bağlantı kurduğunu, iki hanedanlığın (Pers-Sâsânî) kalıntılarının kaynaştıııldığını ve Nakş-i Rüstem bölgesinin Sâsânîler için bir hafıza alanına dönüştüğünü ifade etmektedir (Canepa, 2010). 
$\mathrm{Bu}$ tarz sahneleri I. Şâpur, I. Behram ve Narseh'in kabartmalarında da görmek mümkündür. II. Hüsrev Perviz döneminde ise Tak-1 Bostan rölyefinde diadem getiren bir melek figürü ile karşılaşılmaktadır (Sivrioğlu, 2018, s. 55-56, 60, 70). Söz konusu atanma rölyeflerinde Ahura Mazda ve hükümdar taç giymiş olarak tasvir edilmiştir. Burada Ahura Mazda'nın tacının onun kâinattaki yetkisini, hükümdarın tacının ise onun dünyadaki hâkimiyetini simgelediği ifade edilir (Garthwaite, 2011, s. 93). Sâsâni ikonografisinde önceki dönemlerde görüldüğg̈ üzere kuş motifine de rastlanmaktadır. III. Şâpur'un Tak-1 Bostan'daki betimlemesinde hükümdarın korymbosunun ${ }^{5}$ üzerinde bir şahin figürü bulunmaktadır (Soudavar, 2003, s. 22). Rölyeflerin haricinde bazı Sâsânî sikkelerinde de hükümdar ve tanrı figürleri işlenmiştir. I. Hürmüz'ün sikkelerinin arka yüzünde tasvir edilen hükümdar, sağında bulunan Mithra'ya doğru sağ elini kaldırmaktadır. Tacından da bir 1şık huzmesi çıktığı görülmektedir (Yücel, 2013, s. 98).

Sâsânî ikonografisinde hükümdarın tanrı ile olan bağlantılarını gösteren diğer ferr sembolleri göksel motifler, üç nokta, kurdele ve inci sembolleridir. I. Şâpur'un sikkesinin ön yüzünde hükümdarın alnında üç nokta bulunur. Arka yüzündeki Pâpag'ın alnında da üç nokta tasvir edilmiştir (Yücel, 2013, s. 41). Buradaki üç nokta sembolü, üç takımyıldızı ifade etmektedir. Diğer göksel cisimler ise hilal ve gecenin en parlak yıldızı olan Tir/Tiştrya (Sirius) yıldızıdır. Ayrıca Tak-1 Bostan'daki II. Hüsrev'in rölyefinde ferr'in bir işareti olarak parlak bir nimbus elde etmesi tasvir edilmiştir (Soudavar, 2016, parag. 7, 12). I. Ardeşir'in gümüş drahmisinin her iki yüzünde hükümdarın tacı üzerinde hilal ve yıldız motifleri dikkat çekmektedir. Camasp'ın drahmisinde aynı şekilde bu iki sembol tasvir edilmiştir. Bu tarz örnekleri çoğaltmak mümkündür. Sâsânî ikonografisindeki bu cisimler tanrısal varlıklara atfedilmektedir. Sâsânî öncesinde de kullanılan bu motiflerin, hükümdarın, evrenin düzenleyicisi, kosmokratör olarak görüldüğü bir kraliyet kavramına referans olduğu düşünülmektedir. Hükümdar, dünyayı güneş ve ay gibi aydınlatan bir "dağıtıcı" ve ölümlüler arasında birinci olarak yansıtılmıştır (Göbl, 2006, s. 328; Gariboldi, 2004b, s. 32).

Tanrı ve hükümdar ilişkisinin kurulmasına dair bir başka motif ateşgedelerdir. Ateş sunağı tasvirleri, İran'da Pers döneminden beri kullanılan bir

Korymbos, hükümdarın başının üzerinde ipek benzeri kumaşla kaplı bir saç topuzu gibi tacın üzerinde yükselen küre şeklindeki parçadır. Bu parça Sâsânî kraliyet başlığının en ayırt edici özelliğidir (Brosius, 2006a, s. 163). 
motiftir. Bu motif bütün Sâsânî döneminin hâkim ikonografisi olmuştur (Gariboldi, 2004b, s. 41-42). Sâsânî sikkelerinin arka yüzüne işlenen ateşgedelerin, Pers tahtının temsili olduğu düşünülür (Göbl, 2006, s. 327). I. Ardeşir'in IV. Artabanos'u devirip Sâsânî egemenliğini başlatmasıyla kutsal Zerdüşt ateşi, krallığın sembolü olan Pers tahtı ile birleştirilmiştir. Curtis, Sâsânîlerle birlikte Zerdüşt dininin artık emperyal projenin bir aracı haline geldiğini ifade etmektedir (Curtis, 2016b, s. 186). Zira iktidara gelen Sâsânî hükümdarları, sikkelerinin arkasındaki ateşgede motifinin etrafında kendi adını anarak "kralın ateşi" (Ardeşir'in ateşi, Şâpur'un ateşi vd.) lejantını eklemiştir (Yücel, 2013, s. 50-51, 86). Böylece ateş ve ateş sunağ1 sembolleri her ne kadar hükümdarın dindarlığını yansıtsa da aynı zamanda ferr'in de bir yansıması olarak görülmüştür (Soudavar, 2016, parag. 12).

Bunun yanında Parth sikkelerinde karşılaşılan hükümdarın tanrısallığına dair tartışmalar içeren ifadeler, Sâsânî yazılı kaynaklarında da bulunmaktadır. Bu bakımdan iki ifade dikkat çekmektedir: "bag/bay" ve "yazdân/ yazadân”. Sâsânîlerin kurucusu Ardeşir'in sikkelerinde "bgy p'pky MLKA=bay Pâpag Şah" (tanr1/yüce kral Pâpag'ın oğlu) ifadesi geçmektedir (Beyânî, 2020, s. 26; Yücel, 2013, s. 48). Ardeşir'in Ktesiphon'u ele geçirip devletin sınırlarını Mezopotamya'ya genişletmesinden sonra ise sikkelere "ctry MN yzd'n=čihr az yazdān" (tanrıların soyundan gelen) ifadesi eklenmiştir (Yücel, 2013, s. 46, 59). Ardeşir'in Nakş-i Rüstem'deki yazıtında bay kelimesinin Yunanca karşılığı $\theta \varepsilon$ ó (theos, tanrı) olarak verilmiştir (Alram, vd., 2007, s. 33). Ardeşir'in ardından hükümdar olan I. Şâpur'un Nakş-i Rüstem'deki Kâbe-i Zerdüşt yazıtında da (ŠKZ) $a z$, mazdēzn bay Šäbuhr... kē čihr až yazdān... ifadesi bu noktada dikkat çekmektedir. Daha sonraki bazı hükümdarların sikke lejantlarında da aynı formül bazı değişikliklerle kullanılmaya devam etmiştir (Yücel, 2013, s. 101).

Söz konusu ifadelerden bag/bay kelimesinin Pehlevice'deki sözlük anlamı tanr1, lord (Ahura Mazda), ulu/yüce'dir (Nyberg, 1974, s. 42; MacKenzie, 1986, s. 17). Čihr kelimesi öz, şekil, köken, çehre (Nyberg, 1974, s. 55; MacKenzie, 1986, s. 22); yazdān ise tanrı anlamına gelmektedir (Nyberg, 1974, s. 226). Čihr kelimesinin geçtiği en erken kayıt olan Şâpuragân'da kelime sıklıkla saf 1şıktan oluşan ilahi varlıkların görünümüne ya da parlaklıklarına atıfta bulunmak için kullanılmıştır. Burada kelimenin basit bir "görünüş" olmaktan ziyade görülen ve muhtemelen ayırt edilen "biçim" olarak kullanıldığı ve hem ilahi hem de maddi varlığa atıfta bulunduğu ile- 
ri sürülmektedir (Alram vd., 2007, s. 35). Yazitlarda geçen kē čihr yazadān

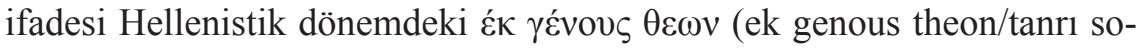
yundan) ifadesinin karş1lı̆̆ olarak görülmektedir (Panaino, 2009, s. 212).

T. Daryaee, bu durumu İran'ın Hellenistik geçmişine bağlamaktadır. Nitekim Büyük İskender ve Seleukoslar kendilerini $\theta \varepsilon$ có olarak görmekteydi. Daryaee de bu ifadenin, erken Sâsânî yazıtlarındaki $M N W$ ctry $M N y z d$ 'n ifadesinin karşılığ 1 olduğunu söyler (Daryaee, 2009, s. 6). Daryaee, ayrıca čihr kelimesinin anlamının erken dönem Sâsânî rölyeflerindeki tanrı ve hükümdar tasvirlerinin "benzerliğini" izah ettiğini düşünmektedir. Nitekim erken dönem Sâsânî rölyeflerindeki Ohrmazd (Ahura Mazda), Mithra veya Anahita, aynı sahnede tasvir edilen Sâsânî hükümdarı ile benzer fiziksel özelliklere ve giysilere sahiptir. Buradan hareketle Daryaee, erken Sâsânî döneminde Zerdüştlüğün, Sâsânî kraliyet ideolojisine bir etkisi olmadığını, Sâsânîlerde gerçekten de erken dönemlerde hükümdarlara tanrısallık atfedildiğini, bu durumun söz konusu dönemin ideolojisi çerçevesinde kutsal bir "İranşehr" yaratmak için oluşturulduğunu; ancak 4. yüzyıldan sonra Zerdüştlüğün güçlenmesiyle böyle bir iddianın ortadan kalktığını, bundan sonra Sâsânî hükümdarlarının tanrılar ve insanlar arasında aracı olan kozmokratöre dönüştüğünü ifade etmektedir (Daryaee, 2008, s. 62-63, 65-67).

A. Soudavar ise tanrı kral imajının İran'ın hükümdarlık geleneğine uymadığını, kè čihr yazdān ifadesinin "dini ve siyasi alanda parlaklık" anlamına geldiğini ifade etmektedir. Bu ifadenin kralların gücünün, zaferlerinin ve ihtişamının iletilmesi ve yayılması için kullanıldığı, böylece čihr kelimesinin ferr sembolü olarak algılanması gerektiği düşünülmektedir (Soudavar, 2016, parag. 12; tartışmalar için bknz. Soudavar, 2012, s. 30-39). Nitekim 4. yüzyılın sonlarından itibaren Sâsânî krallarının "tanrı soyundan gelen" (ctry MN yzd'n) unvanı sikkelerden kaldırılmıştır. Bu durumun Zerdüşt din adamları Kerdir ve Âdurbâd-i Mahrspandan'ın faaliyetleri neticesinde gelişen ve güçlenen Zerdüştlük ile ilgili olduğu ifade edilir. Böylece Sâsânî krallarının ilahi gücü azalmış ve krallar seküler hale gelmiştir. 6. yüzyılda da ideolojik olarak ilahi krallıktan Keyâni Krallığına geçiş olmuştur. Bu doğrultuda Sâsânî kralları artık rām-šahr, hu-kay, kay gibi unvanlar almıştır (Daryaee, 2002, s. 41-43).

Son olarak Sâsânî yazıtlarında -Perslerde olduğu gibi- devletin egemenliğinin engin sınırlarını göstermek için hâkim oldukları memleketlerin listeleri sunulmaktadır. I. Şâpur'un Kâbe-i Zerdüşt yazıtında “Persia, Parthia, Khuzistan, Mesan, Asur (=Babil), Nodširagan [=Adiabene], Arbayestan, Azer- 
baijan, Armenia, Wirzan [=Iberia], Sigan, Albania, Balasagan, Elburz Dağlarının bütün sıras1, Media, Gurgan (Hyrkania), Merv, Harew, ve Abaršahr, Kirman, Sakestan, Tugran, Makran, Pardan, Hindistan, Peşavar'a kadar Kuşan ve Kaşgar'a kadar, Sogdia ve Taşkent, ve Mazun (Umman) denizinin uzak kıy1larına" (ŠKZ 2-5: http://parthiansources.com/texts/skz/skztranslation/) kadar olan memleketlerin ele geçirildiği ifade edilmektedir. Elbette burada Perslerin sahip olduğu Orta ve Batı Anadolu, Avrupa (Skudra) ve Misır gibi coğrafyalardan bahsedilmez. Nitekim bu dönemde söz konusu coğrafyaların Roma'nın nüfuz sahasına girdiği bilinmektedir. Ancak Roma kaynaklarından anlaşılacağı üzere Sâsânîler, Persleri ataları olarak görmüş ve bu toprakların da kendilerinin mirası olduğu iddiasını Romalılara göstermiş ve bildirmiştir (Herodian. VI.II. 1-7; Amm. XVII.5.3-6). Buradan hareketle Sâsânîlerin de kendilerini dünyanın egemeni olarak gördüklerini söyleyebiliriz. Öyle ki Sâsânî sanatında da İran hükümdarının dünyanın merkezinde olduğunu gösteren ikonografilere rastlanmaktadır. Nitekim 6. yüzyıldan kalma bir Sâsânî sikkesinde dört çember üzerinde güneş ve ay sembolleri bulunmaktadır. Bu ikonografiden hareketle T. Daryaee, bunun hükümdarın dünyanın merkezine yerleştirilmesinin, ay ve güneşin de onun etrafinda dönüşünün temsili olduğunu ileri sürmektedir. Sâsânî hükümdarları kendilerini dünyanın dört bir yanının hükümdarı olarak adlandırmıştır. Eski Mezopotamya hükümdarlarının kullandığı ifade olan bu niteleme ile Sâsânî hükümdarı kendisini diğer bütün hükümdarlardan statü bakımından üstün görmüştür. Hatta Sâsânî hükümdarlarının sarayında hükümdarın tahtından daha aşağı seviyede Roma, Türk ve Çin hükümdarları için ayrılmış üç küçük taht bulundurulduğu ifade edilmektedir (Daryaee, 2009, s. 41).

\section{Bulgular}

Eski İran'daki söz konusu hanedanlıklar döneminde iktidarın kaynağı konusunda tanrısal seçim, yetki ve koruma ideolojisi, yazılı ve arkeolojik kaynaklarda sıklıkla işlenen bir temadır. Söz konusu Eski İran hanedanlıklarındaki bu anlayışın kökenleri onların dini inanışının bir gereğidir diyebiliriz. Yazılı metinlerde tanrısal seçim/yetki, ferr (xvarenah) ile ifade edilmiştir. Yine yazılı metinlerde kutsal/tanrısal ışı olarak anılan ferr, genellikle bir hayvan (kuş, koç) şeklinde somutlaştırılmıştır. Metinlerdeki ifadeler İran ikonografisine görsel olarak da yansıtılmıştır. Eski İran ikonografisinde ferr'in nilüfer ve ayçiçeği motifleri ile bağlantılı olduğu an- 
laşılmaktadır. Bunların yanında ay, yıldız gibi ışık saçan göksel cisimler ile halka/yüzük ve ateşgede gibi motifler de hükümdar-tanrı ilişkisi bağlamında işlenmiştir. Bütün bu kanıtlardan anlaşılan, Pers, Parth ve Sâsânî İran'ında, hükümdarın tanrı tarafından yeryüzünü yönetmek için gönderildiğine dair bir "karizmatik hâkimiyet" anlayışının bulunduğudur. Bunun yanında Parth metinlerinde geçen theopatoros, epiphanous gibi ifadelerle Sâsânî metinlerindeki bag/bay, čihr, yazdān ifadeleri, Eski İran hükümdarlık geleneğinde tanrı-kral anlayışı olduğuna dair tartışmaları ortaya çıkarmıştır. Son olarak bu ideolojinin söz konusu hanedanlıklarda dünya hâkimiyeti fikrini de beraberinde getirdiğini ifade edebiliriz.

\section{Tartışma ve Sonuç}

Kaynaklarda ifade edilen ferr ve ferr sembolleri, kutsallığın birer işareti olarak işlenmiştir. Eski İran kaynaklarında ferr'in hükümdarlıkla ilişkilendirilmesi, tanrının ışığının, yani yönetme erkinin tanrı tarafından seçilmiş bir hükümdara ulaştırıldığg anlamına gelmektedir. Anlaşıldığına göre Eski İran'da kraliyetin kutsallığına dair bir düşünce hâkimdi. Hükümdar burada tanrı olarak değil, tanrı tarafından kutsanmış bir beşer olarak ortaya çıkmaktadır. Ancak "sıradan" bir insan da değildir. Tanrı tarafından sıradan insandan daha üstün yetenek ve becerilerle donatılmıştır. Bu noktada Eski İran'da kut anlayışının bulunduğunu ifade edebiliriz. Hükümdarın bu kutsal durumuna dair yazılı ifadeler ile ikonografilerde tanrı ve hükümdarların dış görünüş olarak birbirlerine benzer tasvirleri de "tanrının yeryüzündeki gölgesi”ni yansıtmak için kullanılmış olmalıdır. Bu bakımdan söz konusu durum Müslüman Arap ve Türk devletlerindeki zillullah-i fi'l-arz (Allah'ın yeryüzündeki gölgesi) anlayışı gibi bir durumu yansıtıyor olma1ıdır. Yani hükümdar tanrının bir yansıması olarak dünyanın düzenleyicisidir; tanrının ışığını dünyaya yayandır. Böylece hükümdarın hâkimiyeti de meşrulaşmaktadır.

Kaynaklardan anlaşıldığına göre tanrısal seçim/yetki ideolojisi Pers, Parth ve Sâsânî bağlamında değerlendirildiğinde bir gelenek olarak sürdürülmüştür. $\mathrm{Bu}$ ideolojinin bir propagandanın aracı olduğunu söylemek de mümkündür. Buradaki esas amaç elbette ki hâkimiyetin meşrulaştırılmasıdır. Ancak aynı zamanda hükümdarlığını tanrının izni ve yetkisine bağlayan İran hükümdarları, egemenliği altındaki halkların hükümdara ve ha- 
nedanlığa koşulsuz ve şartsız bağlanmalarını da amaçlamaktaydı. Böylece hükümdara karşı gelen tebaanın tanrıya da karşı geleceği düşüncesi yayılmıştır. Bu amacın iki hedefi olduğunu ifade edebiliriz: İran ve gayri İran. Rölyefler bakımından İran hükümdarlarının Aryan halklarını hedeflediği düşünülebilir. Ancak rölyefler üzerindeki çok dilli yazıtların, diğer halklara da söz konusu mesajı ileten bir araç işlevi gördüğü düşünülebilir. Sikkelerin yayılım potansiyeli düşünüldüğünde ise buradaki hedefin özellikle gayri İran halkları olduğu ifade edilebilir. Sikkeleri politik mesajlar üzerinden değerlendirecek olursak, Pers sikkelerinde tanrısal seçim propagandasının görülmediğini ifade edebiliriz. Ancak Parth ve Sâsânî sikkelerinde tanr1sal seçim mesajı oldukça sık ve yaygın kullanılmıştır. Zira bu dönemlerde İran'ın ciddi bir rakibi bulunmaktaydı: Roma. Belki de Roma'nın Anadolu, Mezopotamya ve Armenia üzerindeki politikaları düşünüldüğünde Parthlar ve Sâsânîler, sikkelerde verdikleri bu mesajla gayri İranî halklara ulaşabilmek ve onların İranlıları desteklemelerini sağlamak için bu ideolojiyi Roma'ya karşı demografik bir "kalkan" oluşturmak için kullanmıştır.

Eski İran'daki tanrısal seçim anlayışı aynı zamanda İran hükümdarlarını ideolojik olarak "dünya kralı" statüsüne ulaştırmıştır. Bu durumun söz konusu Eski İran devletlerinde “dünya hâkimiyeti” fikrini oluşturduğunu ifade edebiliriz. Bu durumla Pers ve Sâsânîlerde karşılaşıldığını söylemeliyiz.

\section{Metinde Kullanılan Yazıt Kısaltma Listesi}

CMa, b : Kyros, Murgab/Pasargad Yazitı.

DB : I. Dareios, Behistun Yazıtı.

DNa : I. Dareios, Nakş-i Rüstem Yazıtı.

DPe $\quad$ : I. Dareios, Persepolis Yazitı.

$\mathrm{A}^{2} \mathrm{Ha}, \mathrm{b} \quad$ : II. Artakserkses, Hemedan Yazitı.

$\mathrm{A}^{2} \mathrm{Sa} \quad$ : II. Artakserkses, Susa Yazitı.

$\mathrm{A}^{3} \mathrm{~Pa} \quad$ : III. Artakserkses, Persepolis Yazitı.

XP, a $\quad$ Kserkses, Persepolis Yazıtı. 
Yazıtlar İçin Kullanılan Metin ve Çeviri: Kent, R.G. (1950). Old Persian grammar, texts, lexicon. American Oriental Society.

ŠKZ : I. Şâpur, Kâbe-i Zerdüşt Yazıtı.

Kullanılan Metin ve Çeviri: http://parthiansources.com/texts/skz/skztranslation/

\section{Metinde Kullanılan Antik Yazar-Eser Kısaltma Listesi}

Amm. (Ammianus Marcellinus, Rerum gestarum Libri)

Kullanılan Metin ve Çeviri: Ammianus Marcellinus. (Çev. J. C. Rolfe). Harvard University Press, 1986; Roma Tarihi. (Çev. S. Özgüler). Historia Yayınları, 2020.

Arr. An. (Arrianus, Anabasis)

Kullanılan Metin ve Çeviri: Anabasis. (Çev. P.A. Brunt). Cambridge, 19761983; Anabasis Alexandri. (Çev. E. Iliff Robson). Book I-IV, Harvard University Press, 1967.

Diod. (Diodorus Siculus, Bibliotheke Historike)

Kullanılan Metin ve Çeviri: Diodorus of Sicily. (Çev. C. Bradford Welles). Books XVI.66-95 and XVII, Cambridge Massachusetts, London, 1963.

FGrHist (Die Fragmente der griechischen Historiker)

Kullanılan Metin ve Çeviriler: F. Jacoby, Die Fragmente der griechischen Historiker, Weiter Teil, A, Berlin, 1926; Ctesias's History of Persia, (Çev. Lloyd Llewellyn Jones, James Robson), Routledge Classical Translation, 2010.

Hdt. (Herodotos)

Kullanılan Metin ve Çeviriler: The Histories. (Çev. A. D. Godley). Harvard University Press, 1920; Tarih. (Çev. M. Ökmen). Türkiye İş Bankas1 Kültür Yayınları, 2009.

Herodian. (Herodianus, Historicus) 
Kullanılan Metin ve Çeviri: History of the Roman Empire From the Death of Marcus Aurelius To the Accession of Gordian III. (Çev. E. C. Echol). University of California Press, 1961.

Ksen. Anab. (Ksenophon, Anabasis)

Kullanılan Metin ve Çeviri: Ksenophon. Anabasis (Onbinlerin Dönüşü). (Çev. Oğuz Yarlıgaş). Kabalcı, 2011.

Plut. Them. (Plutarkhos, Themistokles)

Kullanılan Metin ve Çeviri: Plutarch's lives II, Themistocles and Camillus, Aristides and Cato major, Cimon and Lucullus. (Çev. Bernadotte Perrin). Harvard University Press, 1968.

\section{Beyan}

Bu makale etik kurul kararından muaftır. Çalışmada katılımcı bulunmamaktadır. Çalışma için herhangi bir kurum veya projeden mali destek alınmamıştır. Çalışmada kişiler ve kurumlar arası çıkar çatışması bulunmamaktadır. Telif hakkına sebep olacak bir materyal kullanılmamıştır.

\section{Disclosure}

The article is exempt from the Ethics Committee Decision. There are no participants. The author received no financial support from any institution and there's no conflict of interest. No material subject to copyright is included. 


\section{Kaynakça}

Allen, L. (2005). The Persian empire. The University of Chicago Press.

Alram, M. \& Blet-Lemarquand, M. \& Skjærvø, P.O. (2007). Shapur, king of kings of Iranians and non-Iranians. İçinde R. Gyselen (Ed.), Des Indo-Grecs aux Sassanides: Données Pour l'histoire et la Géographie Historique (Res Orientalis 17) (s. 11-40), Bures-sur-Yvette.

Bakır, A. (2008). Ortaçağ tarihi ve medeniyetine dair çeviriler I. Bizim Büro Basımevi.

Balcı, M. (2016). Taşa kazınmışs sözler: İslâm öncesi Fars öğüt edebiyatı. Büyüyenay Yayınları.

Beyânî, Ș. (2020). Eşkânîlerin (Parthların) düşüşü ve Sâsânîlerin yükselişi. (Çev. A. H. Toğay). Selenge Yayınları.

Briant, P. (2002). From Cyrus to Alexander: A history of the Persian empire. (Çev. P. T. Daniels). Eisenbrauns. (Orijinal yayın tarihi, 1996)

Brosius, M. (2006a). The Persians. Routledge.

Brosius, M. (2006b). The Persian empire from Cyrus II to Artaxerxes I. Lactors.

Calmeyer, P. (2011). Crown i. In the Median and Achaemenid periods. Iranica Encyclopaedia (Online Edition): https://www.iranicaonline. org/articles/crown-i

Canepa, M. P. (2010). Technologies of memory in early Sasanian Iran: Achaemenid sites and Sasanian identity. American Journal of Archaeology, 114(4), 563-596. https://www.jstor.org/stable/25763803

Cereti, C. G. (2011). Kār-nāmag 1 Ardašīì ̄̄ Pābagān. Encyclopaedia Iranica (Online Edition). https://iranicaonline.org/articles/karnamag-iardasir

Choksy, J. (1990). Gesture in ancient Iran and Central Asia II: Proskynesis and the bent forefinger. Bulletin of the Asia Institute, 4, In honor of Richard Nelson Frye: Aspects of Iranian Culture, 201-207. https:// www.jstor.org/stable/24048363

Colburn, H. P. (2014). Art of the Achaemenid empire, and art in the Achaemenid empire. İçinde B. A. Brown, M. H. Feldman (Ed.), Critical approaches to ancient near eastern art (s. 773-800), De Gruyter. 
Curtis, S. V. (2007). The Iranian revival in the Parthian period. İçinde V. S. Curtis, S. Stewart (Ed.), The age of the Parthians: The Idea of Iran II (s. 7-25), I.B. Tauris.

Curtis, S. V. (2016a). İran mitleri. (Çev. F. E. Aslan). Phoenix. (Orijinal yayın tarihi 2010).

Curtis, S. V. (2016b). Ancient Iranian motifs and Zoroastrian iconography. İçinde A. Williams, S. Steward, A. Hintze (Ed.), The Zorastrian Flame exploring religion, history and tradition (s. 179-204), I.B. Tauris.

Darmesteter, J. (1883). The Zend-Avesta: The sirôzahs, yasts, and nyâyis (Part II). Clarendon Press.

Darmesteter, J. (1895). The Zend-Avesta: The vendîdâd (2. bs.). Clarendon Press.

Daryaee, T. (2002). Notes on early Sasanian titulature. Journal of the Society For Ancient Numismatics, XXI, 41-44.

Daryaee, T. (2008). Kingship in early Sasanian Iran. İçinde V. S. Curtis, S. Stewart (Ed.), The idea of Iran III: Sasanian era (s. 60-70), I.B. Tauris.

Daryaee T. (2009). Sasanian Persia: The rise and fall of an empire. I.B. Tauris.

Daryaee, T., Rezakhani, K. (2017). Sasanian empire. İçinde T. Daryaee (Ed.), King of the Seven Climes: A History of the Ancient Iranian World (3000 BCE-651 CE) (s. 155-197), Jordan Centre for Persian Studies.

Ehrenberg E. (2017). Achaemenid visual representations of royal figures. Encyclopaedia Iranica (Online Edition). https://iranicaonline.org/articles/achaemenid-visual-reps

Eliade, M. (1971). Spirit, light, and seed. History of Religions, 11(1), 1-30. http://www.jstor.org/stable/1061780.

Eliade, M. (2017). Dinsel inançlar ve düşünceler tarihi. (Çev. Ali Berktay). Alfa. (Orijinal yayın tarihi 1975).

Finn, J. (2011). Gods, kings, men: trilingual inscriptions and symbolic visualizations in the Achaemenid empire. İçinde J. Lusaka (Ed.), Ars orientalis, 41 (s. 219-275), www.jstor.org/stable/23075965 
Firdevsî (2009). Şahnâme. (Çev. N. Lugal). Kabalcı Yayınevi.

Firdevsî (2020). Şahnâme II. (Çev. N. Yıldırım). Kabalcı Yayınevi.

Frye, R. N. (1964). The charisma of kingship in ancient Iran. Iranica Antiqua, 4, 36-54.

Frye, R. N. (1972). Gestures of deference to royalty in ancient Iran. Iranica Antiqua, 9, 102-107.

Gariboldi, A. (2004a). Royal ideological patterns between Seleucid and Parthian coins: The case of teopator. İçinde R. Rollinger, C. Ulf (Ed.), Commerce and monetary systems in the ancient world (s. 366-384). Verlag.

Gariboldi, A. (2004b). Astral symbology on Iranian coinage. East and West, 54(1/4), 31-53. https://www.jstor.org/stable/29757605

Garrison, M. B. (2011). By the favor of Auramazda: Kingship and th divine in the early Achaemenid period. İçinde P. P. Iossif, A. S. Chankowski, C. C. Lorber (Ed.), More than ten, less than gods studies on royal cult and imperal worship (s. 15-104), Peeters.

Garrison, M. B. \& Root, C. M. (2001). Seals on the Persepolis fortification tablets: Images of heroic encounter, Cilt I, Chicago Oriental Institute Publications.

Garthwaite, G. (2011). İran tarihi Pers imparatorluğundan günümüze. (Çev. F. Aytuna). Inkilâp. (Orijinal yayın tarihi, 2005, 2007).

Gnoli, G. (1999). Farr(ah). Encyclopaedia Iranica (Online Edition). https://www.iranicaonline.org/articles/farrah

Göbl, R. (2006). Sasanian coins. İçinde E. Yarshater (Ed), The Cambridge history of Iran: The Seleucid, Parthian And Sasanian Periods (4. bs.) (s. 322-339), Cilt 3(1), Cambridge University Press.

Güzel, E. (2017). Eski Mısır tarihindeki dinsel yönetim stratejisinin Ptolemaios Hanedanı'ndaki yansıması. Asya Studies, 2, 27-35. https:// doi.org/10.31455/asya.372124

Haerinck, E. (2005). Tang-e Sarvak. Encyclopaedia Iranica (Online Edition). https://www.iranicaonline.org/articles/tang-e-sarvak-1

Hansman, J. F. (2011). Elymais. Encyclopaedia Iranica (Online Edition), https://iranicaonline.org/articles/elymais 
Henning, W. B. (1951). Zoroaster politician or witch-doctor?. Oxford University Press.

Henning, W. B. (1952). The monuments and inscriptions of Tang-i Sarvak. Asia Major, II, 151-178.

Hintze, A. (1994). Zamyād Yašt: Introduction, Avestan text, translation, glossary. Riechert Verlag.

Kafesoğlu, İ. (2005). Türk millî kültürü. Ötüken Yayınları.

Kaptan, D. (2018). Anadolu'da Pers dönemi mühürleri. İçinde K. İren, Ç. Karaöz, Ö. Kasar (Ed.), Persler Anadolu'da: Güç ve Kudret (s. 254267), Yap1 Kredi Yayınları.

Kent, R.G. (1950). Old Persian grammar, texts lexicon. American Oriental Society.

Kuhrt, A. (2019). Eski Çă̆'da Yakındoğu (MÖ 3000-330) (5. bs.). (Çev. D. Şendil). Cilt II, Türkiye İş Bankası Kültür Yayınları. (Orijinal yayın tarihi 1995).

Lerner, J. (2017). Mithradates I and the Parthian archer. İçinde J. Schlude, B. Rubin (Ed.), Arsacids, Romans and local elites: cross-cultural interactions of the Parthian Empire (s. 1-24), Oxbow Books.

Llewellyn-Jones, L. (2017). Achaemenid empire. İçinde T. Daryaee (Ed.), King of the seven climates: a history of the ancient Iranian world (3000 BCE-651 CE) (s. 63-103), Jordan Center for Persian Studies.

Luschey, H. (2011) Ardašīr I ii. rock reliefs. Encyclopaedia Iranica (Online Edition). http://www.iranicaonline.org/articles/ardasir-ii.

MacKenzie, D. N. (1986). A concise Pahlavi dictionary. London University Press.

Malandra, W. W. (1983). An Introduction to ancient Iranian religion reading from Avesta and Achaemenid inscriptions. University of Minnesota Press.

Mann, M. (2012). İktidarın tarihi: Başlangıcından 1760'a kadar toplumsal iktidarın Kaynakları. (Çev. E. Saraçoğlu, S. Torlak, E. Kolay, O. Sevimli). Cilt I, Poenix. (Orijinal yayın tarihi 1995).

Mills, L. H. (1965). The Zend-Avesta: The yasna, visparad, äfrinagān, 
gāhs and miscellaneous fragments (Part III). Motilal Banarsidass.

Nadali, D. (2018). Krallıkların inşa faaliyetleri: Kralın imajı ve eserleri. (Çev. L. Tonguç Basmac1). İçinde U. Eco (Ed.), Antik Yakın Doğu (s. 308-311). Alfa Tarih Yayınları. (Orijinal yayın tarihi 2015).

Nyberg, H. S. (1974). A manuel of Pahlavi II, Weisbaden.

Panaino, A. (2009). The king and the gods in the Sasanian royal ideology. İçinde R. Gylesen (Ed), In Sources pour l'histoire et la géographie du monde iranien (Res Orientales XVIII) (s. 209-256), Peeters.

Peterson, J. H. (Ed.). (2002). Zand-Akasih: Iranian or Greater Bundahishn (Çev. Behramgore Tehmuras Anklesaria). (Elektronik Baskı: http://avesta.org/mp/grb.pdf)

Root, M. C. (1979). The King and kingship in Achaemenid art: Essays on the creation of an iconography of empire. Acta Iranica XIX, Brill.

Sanjana, D. D. P. (Çev.) (1896). Karnâme-î Ardashîr-î Babagân http:// avesta.org/mp/karname.htm

Schlumberger, D. (2007). Parthian art. İçinde E. Yarshater (Ed.), The Cambridge History of Iran, the Seleucid, Parthian and Sasanian periods (5. bs.) (s. 1027-1054), Cilt 3(2), Cambridge University Press.

Schmidt, E. F. (1953). Persepolis I. The University of Chicago Press.

Sellwood, D. (2006). Parthian coins. İçinde E. Yarshater (Ed.), The Cambridge History of Iran: The Seleucid, Parthian and Sasanian periods (4. bs.) (s. 279-198), Cilt 3(1), Cambridge University Press.

Shahbazi, A. S. (1980). An Achaemenid symbol II. farnah '(God given) fortune' symbolised. Archäologische Mitteilungen aus Iran, 13, 119-147.

Sivrioğlu, U. T. (2018). Sāsāniler dönemi İran'da kaya kabartmaları. Arkeoloj ve Sanat, 158, 47-76.

Soudavar, A. (2003). The Aura of kings: Legitimacy and divine sanction in Iranian kingship. Mazda Publishers.

Soudavar, A. (2012). Looking through the two eyes of the earth: A reassessment of Sasanian rock reliefs. Iranian Studies, 45(1), 29-58. https://www.jstor.org/stable/41445196 
Soudavar A. (2016). Farr(ah) ii. Iconography of farr(Ah)/XvArənah. Encyclopaedia Iranica (Online Edition). http://www.iranicaonline. org/articles/farr-ii-iconography

Taberî, (1973). Tarih-i Taberî tercemesi. (Çev. M. Eminoğlu). Cilt II, Can Kitabevi.

Uslu, R. (2001). İstahr. TDV İslam Ansiklopedisi, (C.23, s.202-203). TDV.

Uygun, Ç. (2019). Adana Müzesi'nden diadem örnekleri. OLBA, XXVII, 265-306. https://dergipark.org.tr/tr/pub/olba/issue/47315/596555

West, E. W. (1897). Pahlavi texts V: Marvels of Zoroastrianism. Clarendon.

Wiesehöfer, J. (2003). Antik Pers tarihi. (Çev. M. A. İnci). Telos.

Yarshater, E. (2006a). Iranian common beliefs and world view. İçinde E. Yarshater (Ed.), The Cambridge History of Iran, the Seleucid, Parthian and Sasanian periods (4. bs.) (s. 343-358), Cilt 3(1), Cambridge University Press.

Yarshater, E. (2006b). Iranian national history. İçinde E. Yarshater (Ed.), The Cambridge History of Iran, the Seleucid, Parthian and Sasanian Periods (4. bs.) (s. 359-481), Cilt 3(1), Cambridge University Press.

Y1ldırım, N. (2008). Fars mitolojisi sözlüğü. Kabalc1 Yayınevi.

Yurtsever, A. (2015). Neokoros düşüncesinin kökeni ve gelişimi: Tanrı, kutsal krallık ve yönetici ilişkisi. Anadolu Üniversitesi Sosyal Bilimler Dergisi, 15(2), 1-16. https://doi.org/10.18037/ausbd.66091

Yücel, M. (2013). Erken dönem Sasani tarihi ve sikkeleri [Yayımlanmamış yüksek lisans tezi], İstanbul Üniversitesi Sosyal Bilimler Enstitüsü.

Zerrinkûb, A. \& Zerrinkûb, R. (2019). Sâsânîlerin siyasî tarihi. (Çev. A. Hüseyin Toğay). Önsöz Yayınc1lı. 